\title{
PRAWA OBJAWIENIA BIBLIJNEGO: CIĄGEOŚĆ I TRANSPOZYCJA W UJĘCIU LISTU DO HEBRAJCZYKÓW
}

„Pismo święte - jak stwierdza Sobór Watykański II w konstytucji dogmatycznej Dei Verbum - jest mową Bożą, utrwaloną pod natchnieniem Ducha Swiętego na piśmie”. Jest ono odbiciem tego szczególnego dialogu, który Bóg prowadził z ludzkością, a którego celem było objawienie się Boga i pouczenie człowieka o najważniejszych dla niego prawdach. Bóg więc objawiający się przez swoje czyny i słowa, w Piśmie świętym pozwala prześledzić nam drogę tego objawiania się i rozpoznać jego specyficzne cechy. Objawienie też jest pouczeniem.

Kiedy natomiast szukamy jakiegoś modelu, który przybliżałby nam sposób tego pouczenia, trzeba stwierdzić, że Bóg poucza ludzi na sposób domowej katechezy, prowadzonej przez rodziców, a szczególnie przez matkę, a nie na sposób szkolnego wykładu. Wykład odznacza się swoistą systematycznością, która wyraża się we właściwym rozłożeniu materiału poznawczego, ułożeniu go według pewnych działów, które kolejno są przechodzone i jednorazowo wyczerpywane. Materiał wykładu rozpoczyna się od zagadnień wstępnych, aby później przechodzić do problemów coraz bardziej złożonych, wymagających dla swego zrozumienia opanowania poprzednio wyłożonego materiału. Raz podjęty temat w wykładzie zwłaszcza akademickim, rozpracowany jest wyczerpująco i nie ma potrzeby powracania do jego wykładu, najwyżej przywołuje się go w pamięci słuchaczy, aby służył za odskocznię do przedstawienia dalszych części wykładu, logicznie stanowiących jakby następne, choć już odrębne piętro. Pismo święte nie jest takim wykładem prawd objawionych przez Boga. Raczej daje się porównać do domowej katechezy, która nie ma z góry wyznaczonego programu, najczęściej odbywa się data occasione i porusza w danym momencie aktualne problemy. Nie ma tu także wyczerpującego traktowania poszczególnych tematów. Dziecku przekazuje się tyle wiadomości, ile może ono na danym poziomie swego rozwoju zrozumieć i ile potrzeba, aby zaspokoić ciekawość lub skłonić do właściwego postępowania. Dlatego w ten sposób wymaga logicznych powtórzeń dla kolejnych rozwinięć tematu, a także ze względu na charakterystyczne dla dziecka zapominanie.

Bóg, który postanowił objawić się w historii i poprzez historię, przyjął taki właśnie, „domowy” sposób pouczenia. Objawiał się stopniowo i często powra- 
cał do tych samych spraw, przeważnie z powodu twardości karku tego narodu, któremu objawienie zostało przekazywane i który miał wypełniać zawarte z Bogiem przymierze, a raz po raz od tego odstępował. Bóg objawiał się stopniowo, stąd objawienie biblijne charakteryzuje się stałym rozwojem. Rozwój ten jest ciągły w tym sensie, że objawienie biblijne stanowi zwartą całość, bardzo ściśle powiązaną ze sobą. Wyrazem ciągłości objawienia jest więź typologiczna, dzięki której Stary Testament proroczo zapowiada i oznacza rozmaitymi obrazami nadejście Chrystusa oraz królestwa mesjańskiego ${ }^{1}$, a Nowy Testament ukazuje realizacje tych zapowiedzi.

Stary i Nowy Testament, ściśle ze sobą złączone, zawierają prawdę objawioną w taki sposób, który zostal przez św. Augustyna ujęty w lapidarnej i peInej treści zasadzie: In Vetere Novum latet et in Novo Vetus patet ${ }^{2}$. Zasada ta, która przez specjalistów skrótowo określana jest zasadą latet - patet, może być przetłumaczona na język polski następująco: w Starym Nowy się kryje, a w Nowym Stary nabiera blasku. Przytoczona zasada ukazuje następną charakterystyczną cechę objawienia biblijnego, którą nazywamy transpozycją. Między Starym a Nowym Testamentem istnieje ścisła łączność w myśl wspomnianej już ciągłości objawienia, ale nieprzerwany i istotny rozwój objawienia sprawia, że prawda odsłania się w Nowym Testamencie w całej pełni, tak bogatej, że możemy mówić jakby o przeniesieniu na inny, wyższy poziom. Pewną ilustracją transpozycji jako cechy objawienia biblijnego może być zakwitnięcie rośliny. Rośnie ona, wypuszcza korzenie i łodygi, ale w pełni okazuje się w kwieciu. Kwiat jest kolejnym etapem wzrostu, a jednak stanowi pewną nową jakość, nadającą sens i korzeniom i łodydze i oczywiście całości. Bez korzenia i łodygi kwiatu ani uchować, ani zrozumieć nie można, ale bez kwiatu korzeń i łodyga nie przedstawiają jeszcze swojej wartości.

Objawienie biblijne zatem rządzi się trzema prawami: prawem rozwoju, prawem ciągłości i prawem transpozycji. List do Hebrajczyków, jako jedno z pism Nowego Testamentu, jest również ogniwem realizującym prawo biblijnego rozwoju, w tym Liście natomiast bardzo wyraźnie ukazane są dwa następne prawa i przedstawienie tego ich ujęcia jest przedmiotem niniejszego opracowania. Zanim jednak podjęta zostanie jego właściwa tematyka, trzeba bliżej scharakteryzować sam List. Ta bowiem charakteryzacja, nawiązująca do zagadnienia powstania Listu, przyczyni się do lepszego zrozumienia samej podjętej tematyki, a przede wszystkim posłuży wyjaśnieniu samego faktu tak dobitnego miejsca ciągłości i transpozycji w Liście do Hebrajczyków.

List do Hebrajczyków jest bez wątpienia pismem specyficznym. Już od starożytności dyskutowana jest sprawa autorstwa tego Listu, a jego interpretacja także rodzi liczne dyskusje. Nie wchodząc tu w dalsze szczególy, dla wyjaśnie-

\footnotetext{
${ }^{1}$ Por. Dei Verbum, 15.

${ }^{2}$ Qu. in Hept. 2,73, PL 34, 263.
} 
nia naszego problemu trzeba nawiązać do wysuniętej hipotezy, według której List do Hebrajczyków jest kontynuacją niedokończonej Mowy Szczepana, znanej nam z Dziejów Apostolskich ${ }^{3}$. Takie ujęcie genezy Listu tłumaczy, wydaje się zadowalająco, specyfikę jego tematyki i sposobu jej wykładu.

Szczepan został oskarżony przez Żydów o to, że występuje przeciw miejscu świętemu i przeciw Prawu, gdyż głosi, że Jezus Nazarejczyk zburzy świątynię i pozmienia zwyczaje, przekazane przez Mojżesza (Dz 6, 13 n). Mowa obronna Szczepana, umieszczona w siódmym rozdziale Dziejów Apostolskich, jest odpowiedzią na postawione zarzuty. Składa się ona z długiego wywodu historycznego, w którym Szczepan omawia dzieje Izraela od powołania Abrahama. W ramach tych dziejów bardziej szczegółowo omówione są postać i dzieło Mojżesza oraz sprawa przybytku, zbudowanego przez Mojżesza na pustyni i jego kontynuacji przez świątynię Salomona. Linia obrony idzie więc tu przez ukazanie pozytywnego stosunku Szczepana do całego religijnego dziedzictwa Izraela. Nie występuje on ani przeciw świątyni ani przeciw Prawu, które nazywa słowami życia. Oskarżony jest o sprzeciw, ale w całej historii Izraela to właśnie Żydzi sprzeciwiali się, nie chcieli słuchać Mojżesza, zwracali serca ku obcym bogom, prześladowali proroków. To oni zasługują na zarzut, że sprzeciwiają się Duchowi Świętemu, nie przestrzegają Prawa, a potwierdzili to odrzucając i mordując Sprawiedliwego, jak Szczepan określa Jezusa. Oskarżenie dotyczyło Jezusa i Jego dzieła, które oskarżyciele interpretowali jako zamach na swoje największe wartości religijne. Pozytywny wykład historii przeprowadzony przez Szczepana powinien rozwiać ich zastrzeżenia, co do destruktywnej roli przypisywanej Jezusowi. Szczepan, występujący jako uczeń Jezusa, nie ma ochoty potępiać i odrzucać przeszłości i jej wartości, ale pozostaje jeszcze konstruktywna rola Jezusa, jeżeli jest On Kimś, kogo Szczepan z taką gorliwością głosi. O tej roli Jezusa Szczepan nie mógł już powiedzieć, gdyż został wyrzucony za miasto i ukamienowany. Mowa Szczepana została urwana. Jeżeli przedstawiona w Dziejach Apostolskich mowa idzie po linii ciągłości, to wyraźnie brakuje w niej ukazania transpozycji związanej z dziełem Chrystusa. Wtedy dopiero mielibyśmy pełną odpowiedź na postawione zarzuty. Szczepan, głosząc naukę Jezusa, nie występuje przeciw świątyni i Prawu, gdyż uważa je za prawdziwe wartości, ale równocześnie ukazuje, że Jezus przynosi bogatszą rzeczywistość, przewyższającą to, co było dane Izraelowi, i dlatego, nie odrzucając ani zwalczając, usuwa jakby w cień to, co było. W imię zatem wierności Prawu i świątyni, jako podstawowym wartościom religii Mojżeszowej, należy przyjąć naukę Jezusa i przyniesione przez Niego dobra. Przeciwnicy Szczepana nie usłyszeli tej argumentacji. Bojąc się jej logicznego toku, sięgnęli po fatalne argumenty kamieni i zamknęli usta głoszące im prawdę. Sprawiedliwy jednak

${ }^{3}$ Por. T. J el o n e k, Problem autorstwa Listu do Hebrajczyków, „Analecta Cracoviensia” 18 (1986) s. 205-245. 
mówi nawet po śmierci (Hbr 11,4). Niedokończona mowa Szczepana znalazła swoje dokończenie w Liście do Hebrajczyków, o czym mogą świadczyć liczne związki między Mową Szczepana i Listem do Hebrajczyków, a szczególnie między obecnym zakończeniem Mowy a prologiem Listu do Hebrajczyków.

Jeśli List do Hebrajczyków jest kontynuacją niedokończonej Mowy Szczepana, to stanowi on odpowiedź na oskarżenie skierowane przeciw Szczepanowi. Idąc natomiast za tokiem rozumowania, jaki przyjęła Szczepanowa linia obrony, List do Hebrajczyków podejmuje sprawę ciągłości starego i nowego przymierza oraz sprawę transpozycji związanej z dziełem Chrystusa. Tak więc problem ciągłości i transpozycji jest najbardziej konstytutywnym problemem Listu do Hebrajczyków, stanowi fundament całej jego nauki. Zachowanie ciągłości i ukazanie transpozycji jest naczelną ideą Listu, której jest on wierny we wszystkich szczegółowych swych rozważaniach. Wydaje się, że w ten sposób można najogólniej, a równocześnie najpełniej określić treść Listu do Hebrajczyków, tę treść, która w swym opracowaniu sprawiała i sprawia wiele kłopotów egzegetom zajmującym się tym Listem. Tak sformułowanej naczelnej idei Listu podporządkowane są poszczególne tematy podejmowane przez Autora i z niej również płynie główne parenetyczne wezwanie do wierności. Nie można bowiem kontynuować fatalnego ciągu niewierności, jaki towarzyszył historii Izraela, wyższa natomiast rzeczywistość nowego przymierza jeszcze bardziej wymaga wierności.

Po ogólnym zaznaczeniu miejsca problematyki ciągłości i transpozycji w Liście do Hebrajczyków poruszymy kilka konkretnych spraw, aby w ten sposób dojść do sformułowania specyficznych cech ujęcia tej problematyki w Liście do Hebrajczyków.

Rozważana problematyka pojawia się już w pierwszych zdaniach Listu, które stanowią jego prolog. W wielkim skrócie ukazane są tu dzieje objawienia, które dokonało się w dwu etapach. Pierwszym było wielokrotne i wielorakie przemawianie Boga do ludzi przez proroków. Było to stopniowe, ale też częściowe objawianie Bożej prawdy, której głosicieli było wielu. Drugi etap jest kontynuacją pierwszego, dokonującą się w dniach ostatecznych. Bóg przemawia przez Syna. Wielu pośrednikom objawienia w pierwszym etapie odpowiada jeden pośrednik ostatecznego objawienia. O Nim w dalszych wierszach prologu zostanie powiedziane wiele. Jak wiemy, prolog Listu do Hebrajczyków przedstawia bardzo bogatą chrystologię ${ }^{4}$. Syn jest ustanowiony dziedzicem wszystkich rzeczy, przez Niego zostal stworzony wszechświat. Syn, który jest odblaskiem chwały Ojca i odbiciem jego istoty, podtrzymuje wszystko słowem swej potęgi. On dokonał oczyszczenia z grzechów i zasiadł po prawicy majestatu na wysokościach. Podkreślenie wielkości i godności Syna ukazuje

${ }^{4}$ Por.A. Van hoye, Christologia a qua initium sumit epistola ad Hebraeos (Hebr 1,2.3.4), „Verbum Domini” 43 (1965) s. 3-14, 49-61, 113-123. 
transcendencję, jaka dokonuje się w drugim z wyróżnionych etapów objawienia. Wielości pośredników przeciwstawiony jest jeden, dawnym czasom, określonym jako „niegdyś”, przeciwstawiony jest czas ostateczny, prorokom przeciwstawiony jest Syn. Te ważne przeciwstawienia odnoszą się jednak do jednej i tej samej objawiającej działalności Boga, który przemówiwszy w prorokach, przemówił również w Synu. Wyrazem tej ciągłości może być także użycie dwu form tego samego czasownika laleō. Prolog Listu do Hebrajczyków słusznie uważany jest przez egzegetów za swoiste streszczenie całości. Jak widzimy, streszczenie to ukazuje dobitnie ciągłość i transcendencję objawienia Bożego, te dwa prawa, które rządzą objawieniem biblijnym.

To, co znalazło tak dobitny wyraz w prologu, jest również obecne w dalszych częściach Listu. Jego strukturę literacką, wykazującą zwartą i systematyczną budowę, przedstawil A. Vanhoye ${ }^{5}$. Oprócz prologu $(1,1-4)$ i konkluzji $(13,20$-21) Vanhoye wyróżnia pięć części Listu. Część pierwsza $(1,5-2,18)$ ma charakter przeważnie doktrynalny i ukazuje wyższość Chrystusa nad aniołami. Jest to znów ukazanie ciągłości objawienia i zbawczego działania Boga. Judaizm bowiem aniołom przypisywał rolę pośredników w zawarciu przymierza synajskiego. Ten pogląd przejmuje Autor Listu do Hebrajczyków i pośrednikom tamtego przymierza przeciwstawia pośrednika przymierza nowego. Ten pośrednik otrzymał wyższe imię, On jest Synem, któremu pokłon mają oddać wszyscy aniołowie. Aniołowie zaś są tylko sługami, duchami przeznaczonymi do usług. Objawiona przez aniołów mowa była mocna, ale nowe przymierze daje zbawienie, uwierzytelnione nie tylko cudami i znakami, jak przymierze synajskie, ale również różnorakimi mocami i udzieleniami Ducha ${ }^{6}$. Obserwujemy zatem jedną, ciąglą ekonomię zbawczą Boga, która znów obejmuje dwa etapy. Pierwszy ukazany jest jako rzeczywistość bardzo pozytywna, mowa aniołów nazwana jest mocną, drugi jednak jest o wiele doskonalszy. Rozważana więc pierwsza część Listu bardzo wyraźnie podkreśla i ciągłość i transpozycję. Już tu widzimy, że nowa rzeczywistość nieskończenie przerasta poprzedni etap. To przerastanie zilustrowane jest następującym cytatem z Psalmu 102:

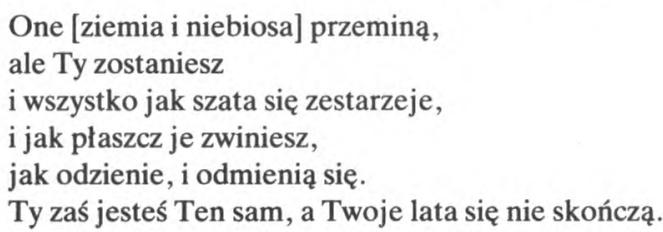

Te słowa skierowane do Syna, który jest wyższy od aniołów, zapewniają o wyższości nowego przymierza.

${ }^{5}$ La structure littéraire de l'Ẽ pître aux Hébreux (Studia Neo-testamentica 1), Desclée 1963.

6 Por. T. Je lo n e k, Poświadczające dzieta Boga wedtug Hbr 2,4. „Ruch Biblijny i Liturgiczny" 31 (1978) s. 16-22. 
Problematyka ciągłości i transpozycji pojawia się również w drugiej części Listu $(3,1-5,10)$, wyróżnionej przez Vanhoye'a. Ukazuje ona przede wszystkim Jezusa jako kapłana wiernego i współczującego. Jezus, wierny Temu, który Go uczynił, przyrównany jest do Mojżesza. Występująca tu typologia Mojżesz - Chrystus podkreśla ciągłość Bożej ekonomii zbawczej, ale równocześnie wykazuje wyższość Chrystusa. Mojżesz był wierny. Podobnie, jak poprzednio, List do Hebrajczyków nie przekreśla rzeczywistości starego przymierza, przeciwnie, stara się podkreślić jej pozytywne strony. Przymierze, zawarte za pośrednictwem aniołów, zostało nazwane mocną mową, w postaci Mojżesza podkreślona jest wierność w całym domu Bożym. Wierność w tym miejscu, zastosowana również do Jezusa, oznacza nie tylko podjęcie i wypełnienie woli Bożej, ale także to, że wierny jest stałym oparciem dla innych, wiernemu można zaufać i liczyć na niego ${ }^{7}$. Takim był Mojżesz. List do Hebrajczyków ocenia go wysoko, jest przecież pośrednio odpowiedzią na zarzut występowania Szczepana i Jezusa przeciw Mojżeszowi. Mojżesz był wierny, ale jako sługa na świadectwo tego, co miało być powiedziane. Mojżesz jest ogniwem, ale objawienie jest kontynuowane. Już w Mojżeszu zapowiedziana jest kontynuacja i dzięki takiemu układowi jest ona ciągła. Przede wszystkim jednak nastąpić musi transpozycja. Mojżesz był wierny w domu, Chrystus zaś, jako Syn, jest nad swoim domem. Dlatego o tyle wyższej czci godzien jest od Mojżesza, o ile większą cześć od domu ma jego budowniczy. Wyrazem ciągłości całej ekonomii zbawczej jest również w tej części Listu problem aktualności wejścia do odpoczynku. Dążyli do niego Izraelici przez pustynię, nie wprowadził ich do niego Jozue, adresaci Listu są napominani, aby spieszyli się wejść. Nie mogą naśladować bowiem nieposłuszeństwa Izraelitów, aby mogli odpocząć po swoich czynach, jak Bóg po swoich. Mają natomiast większe szanse, niż poprzednicy, mają bowiem arcykapłana, który może współczuć ich słabościom, gdyż jest doświadczony we wszystkim na nasze podobieństwo, z wyjątkiem grzechu. On to, gdy wszystko wykonał, stał się sprawcą zbawienia wiecznego dla wszystkich, którzy Go słuchają. Tak więc ukazana ciągłość przechodzi w toku rozumowania Listu w podkreślenie transcendencji. Sytuacja chrześcijan jest o wiele donioślejsza, gdyż mogą zbliżyć się z ufnością do tronu łaski.

Trzecia, centralna część Listu $(5,11-10,39)$ ukazuje Jezusa jako arcykapłana nowego przymierza. Kapłaństwo i przymierze łączą się bowiem bardzo silnie. Ze zmianą jednego następuje zmiana drugiego. Problem kapłaństwa jest ściśle związany z całym kultem, a w szczególności z miejscem sprawowania kultycznych czynności kapłańskich, a więc z miejscem świętym, sanktuarium, świątynią. Centralna więc część Listu wprost wiąże się z obu zarzutami wytoczonymi Szczepanowi, z zarzutem występowania przeciw prawom Mojżesza, będącym wyrazem przymierza i z zarzutem wrogości względem miejsca święte-

${ }^{7}$ Por. A. V a n h oy e, Jesus ,fidelis ei qui fecit eum” (Hebr 3,2), „Verbum Domini” 45 (1967) s. $291-305$. 
go. Najpierw ukazana jest wyższość Jezusa - arcykapłana, który stał się poręczycielem lepszego przymierza. On ma kapłaństwo nieprzemijające, jest kapłanem świętym, niewinnym, nieskalanym, oddzielonym od grzeszników, wywyższonym ponad niebiosa, który raz na zawsze złożył ofiarę z samego siebie. „Prawo bowiem ustanawiało arcykapłanami ludzi obciążonych słabością, słowo zaś przysięgi, złożonej po nadaniu prawa, ustanawia Syna doskonałego na wieki" $(7,28)$. Następnie Autor Listu do Hebrajczyków przechodzi do ukazania wyższości świątyni Chrystusowej i nowego przymierza. Chrystus bowiem jest sługą świątyni i prawdziwego przybytku zbudowanego przez Pana, a nie przez człowieka. Jego służba jest wznioślejsza, gdyż opiera się na lepszych obietnicach. Słabość poprzedniego przymierza wymagała przymierza lepszego. Zostało ono zapowiedziane już przez proroka Jeremiasza, którego dłuższy cytat włączony został do rozważań Listu. Pierwsze przymierze miało przepisy służby Bożej i ziemski przybytek. Dary tam jednak składane nie mogły udoskonalić w sumieniu spełniających służbę Bożą. Przepisy tej służby kultycznej zostały nałożone do czasu naprawy. Kiedy więc zjawił się Chrystus, zdobył wieczne odkupienie i złożył nieskalaną ofiarę, która oczyszcza sumienia z martwych uczynków i uzdalnia do służby Bogu żywemu. Ofiary pierwszego przymierza, choć składane na podstawie Prawa, nie mogły podobać się Bogu. Dlatego zostały usunięte, a ustanowiona została nowa ofiara, udoskonalająca tych, którzy są uświęcani.

Rozumowanie Autora Listu do Hebrajczyków, które tu staraliśmy się przedstawić w wielkim skrócie, ukazuje znów interesujące nas prawa ciągłości i transpozycji. Mówiąc o kulcie starotestamentalnym Autor nazywa go obrazami rzeczy niebieskich, podkreślając w ten sposób typologiczną więź starego i nowego kultu. Więź typologiczna świadczy o ciągłości. Dlatego ukazana jest słabość, niewystarczalność, przemijalność tego, co wiązało się z pierwszym przymierzem, ale nigdzie nie zostaje ono potępione lub uznane za złe. Owszem, wyraźnie zostało podkreślone Boże ustanowienie tamtego kultu. Nowy kult i nowe kapłaństwo, jak również nowe przymierze, jest doskonalsze, nieskończenie doskonalsze, ale jest dalszym ciągiem, uzupełnieniem, wypełnieniem poprzedniego, a nie jego zaprzeczeniem. Transpozycja natomiast, która dokonuje się w nowym przymierzu, a której wyrazem jest między innymi zastąpienie krwi kozłów i cielców krwią Chrystusa przez Ducha wiecznego złożoną Bogu jako nieskalana ofiara, sprawia, że to, co było, staje się zaledwie obrazem, a nawet cieniem dóbr przyszłych. Przejście od cienia do pełnej realizacji jest wyrazem prawa transpozycji, które bardzo wyraźnie uzupełnia prawo ciągłości. Dlatego Jezus, a w jego imieniu Szczepan, nie występował przeciw Prawu Mojżesza, ani przeciw świątyni. Ich typiczna rola była czasowa, pozostała ich własna wartość, ale w świetle nowej rzeczywistości stała się tylko cieniem. Zarzut wrogości jest nieuzasadniony. Prawo ciągłości wymaga dalszego rozwoju, przejścia od typu do antytypu. Ten antytyp wykaże, że starotesta- 
mentalnym wartościom daleko do pełni. Nie należy więc przy nich zostawać. Właśnie wierność tym wartościom nakazuje przyjąć nowość Chrystusowego przymierza. Chrystus nie zmienia, ale doskonali zwyczaje Prawa, Chrystus nie burzy świątyni, ale prowadzi do nowego przybytku, nie ręką ludzką zbudowanego. Kto zostaje przy starym prawie i dawnej świątyni, ten nie zrozumiał ich właściwego sensu, sensu typicznego, a tym samym im się sprzeciwił.

Taka obrona Szczepana wynika z rozważań Autora Listu do Hebrajczyków. Tego wszystkiego Szczepan nie miał możliwości powiedzieć swoim oskarżycielom. List do Hebrajczyków podejmując niedokończoną mowę Szczepana doprowadza argumentację do końca. Pisany jest jednak w wiele lat po śmierci Szczepana i w zupełnie nowej sytuacji. Jego adresatami są już nie prześladowcy Szczepana, ale chrześcijanie drugiej generacji, którzy zapominają czasem o wielkości otrzymanego daru. Dlatego narażają się na surowszą karę niż przewidziana była w prawie Mojżeszowym (znów podkreślenie ciągłości i transpozycji). Tam groziła śmierć bez miłosierdzia, teraz trzeba pamiętać, że straszną rzeczą jest wpaść w ręce Boga żyjącego, jeżeli bezcześci się krew uświęcającego przymierza i obelżywie zachowuje wobec Ducha łaski. Ukazanie transpozycji rzeczywistości nowego przymierza służy wezwaniu do wierności.

Czwarta część Listu $(11,1-12,13)$ w długim wywodzie przedstawia najpierw przykłady wiary, przedstawiając tym samym skróconą historię czasów Starego Testamentu. Pod tym względem ten fragment Listu do Hebrajczyków upodabnia się bardzo do Mowy Szczepana. Przeprowadzony tu przegląd wielokrotnie ukazuje typiczny charakter dziejów Starego Testamentu. Dzieje te były skierowane ku przyszłości, w której miało nastąpić wypełnienie tego, co poprzednio zostało już zapowiedziane. Ukazuje się zatem historia jako stopniowe wypełnianie zbawczego planu Boga, zdążającego do pełnego zbawienia. Tak przedstawiona historia nie jest zbiorem poszczególnych postaci i faktów, ale stanowi jedną, zwartą i ciągłą całość, której uzupełnieniem i wypełnieniem jest rzeczywistość przyniesiona przez Chrystusa. Dlatego na końcu całego przeglądu Autor, zwracając się do adresatów, pisze, że Bóg nam lepszy los zgotował. Cały przegląd dziejów podkreśla wiarę wielkich postaci Starego Testamentu, ale nam w wierze przewodzi i ją wydoskonala Jezus. Chociaż omawiana obecnie część Listu nie podejmuje tak generalnie problematyki transpozycji, jak to śledziliśmy w poprzednich częściach, to jednak to skierowanie wzroku na Jezusa stanowi wyraźne podkreślenie tego tak istotnego prawa. Jezus wydoskonala wiarę. Dlatego nowe przymierze stanowi rzeczywistość przyniesioną na wyższy poziom. Dokonuje się transpozycja. Równocześnie jest ona zobowiązaniem. „Winniśmy wytrwale biec w wyznaczonych nam zawodach” $(12,1)$. Wznioślejsza rzeczywistość, której chrześcijanie stają się uczestnikami, wymaga od nich większej wierności. Wezwanie do wierności jest stałym elementem pouczeń Listu do Hebrajczyków.

Piąta, ostatnia część Listu do Hebrajczyków $(12,14$ - 13,19) zawiera bar- 
dzo wyraźne przeciwstawienie (12,18-24), które charakteryzuje się dwukrotnym użyciem czasownika proserchomai mającego znaczenie kultyczne. Obrazuje to nieprzystąpienie chrześcijan do pierwszego etapu ekonomii zbawienia $\mathrm{i}$ ich przystąpienie do etapu drugiego. Etapem pierwszym jest przymierze synajskie, etapem drugim przymierze nowe, którego sprawcą jego Chrystus ${ }^{8}$. Poznanie struktury literackiej rozważanej perykopy upoważnia do stwierdzenia, że nie mamy tu do czynienia z przeciwstawieniem dwu przymierzy charakteryzowanych przez dwie góry: Synaj i Syjon, jak to uważają niektórzy egzegeci. Nie mamy tu także przeciwstawienia przymierza nowego staremu przymierzu, jak to spotykamy w pismach św. Pawła (por. Ga 4,24 nn). Autor przede wszystkim podkreśla jedność ekonomii Bożej. Rozważana perykopa, podobnie jak inne miejsca Listu, uwzględnia i silnie akcentuje ciągłość objawienia i ciągłość zbawczych interwencji Boga. Dlatego przymierze Chrystusowe w tym jednym jedynym miejscu Nowego Testamentu nazwane jest nie nowym (kai$n \bar{e})$, lecz odnowionym (nea diathēkē). Można wskazać także inne zabiegi literackie, podkreślające ciągłość obu etapów ekonomii zbawienia, które są tu przedstawione. Pierwszy z nich był niedoskonały, kruchy, chwiejny i niewystarczający, objawiony przy pomocy materialnych znaków. Drugi jest doskonały, trwały, mocny, przebogaty. Autor nie przeciwstawia sobie obu przymierzy, ale te właśnie, wymienione wyżej, ich aspekty. Pierwszy etap nazywa dotykalnym i wkłada w ten termin bogatą treść. Chrześcijanie nie przystąpili do tego, co dotykalne. Drugi etap określony jest jako Syjon Nowego Przymierza. Jest to realizacja zapowiedzi proroków Starego Testamentu, rzeczywistość z natury swej eschatologiczna, rozpoczynająca się już tu i teraz. Chrześcijanie przystą̧pili do Góry Syjon. Chrześcijanie nie przystąpili do tego, co dotykalne, rzeczywistość, do której przystąpili, jest kontynuacją przymierza synajskiego, ale odnowioną przez nowego pośrednika - Jezusa. Przystępują przez nowego pośrednika Jezusa. Przystępują przez krew pokropienia (nie pokropienie krwią, jak ma większość przekładów), do miasta Boga żyjącego, w którym są współobywatelami aniołów i dusz, które już osiągnęły swój cel. Tu na ziemi stanowią zgromadzenie pierworodnych, ale zapisani są w niebiosach, gdzie czeka ich Bóg Sędzia wszystkich. Sąd, jak zawsze w teologii Syjonu ${ }^{9}$, jest ujawnieniem sprawiedliwości sprawiedliwych, którzy w ten sposób osiągają doskonałość, a dla niezbożnych jest wykazaniem ich niegodziwości i klęski. Chrześcijanin jednak z ufnością może przystąpić do Boga Sędziego, jeżeli dochowa wierności temu, do czego przystąpił, a rzeczywistość ta, w odróżnieniu od dotykalności poprzedniego etapu, dysponuje odpowiednią mocą. W omawianym przeciwstawieniu podkreślaliśmy już wyakcentowanie ciągłości. Przymierze nowe nie jest przeciwstawione przymierzu synajskiemu, choć T. Rakoczy podsumował opinie

${ }^{8}$ Por. T. J elon e k, „Dotykalne” $i$ „Góra Syjon”. Wtaściwa treść przeciwstawienia w Hbr 12,18-24, „Analecta Cracoviensia” 9(1977) s. 139-154.

${ }^{9}$ Por. T. J el o n e k, Starotestamentalna teologia Syjonu, tamże 19 (1987) s. 441 - 458. 
większości komentatorów w następujących słowach: „W powyższych wierszach zawiera się owo słynne przeciwstawienie Starego i Nowego Przymierza, jako przeciwstawienie dwu gór charakteryzujących te przymierza"10. Takiego przeciwstawienia List do Hebrajczyków nie zawiera. Przeciwstawia jedynie doskonałość przymierza nowego słabości starego. Same przymierza są realizacją jednego, ciągłego planu zbawczego. Przeciwstawienie natomiast ukazane przez Autora Listu do Hebrajczyków służy podkreśleniu transpozycji, a równocześnie, jak to już śledziliśmy kilkakrotnie, przez ukazanie transpozycji prowadzi do usilnego wezwania do wierności. „Strzeżcie się, abyście nie stawiali oporu Temu, który do was przemawia. Jeśli bowiem tamci nie uniknęli kary, ponieważ odwrócili się od Tego, który na ziemi mówil, o ileż bardziej my, jeżeli odwrócimy się od Tego, który z nieba przemawia” $(12,25)$. „Dlatego też otrzymując niewzruszone królestwo, trwajmy w łasce, a przez nią służmy Bogu ze czcią i bojaźnią" $(12,28)$.

Dokonaliśmy szczegółowego przeglądu treści calego Listu do Hebrajczyków, zajmując się w poszczególnych częściach Listu (podział Listu przyjęliśmy za Vanhoyem) przedstawieniem ciągłości i transpozycji. Okazuje się, że problematyka ta jest obecna we wszystkich pięciu wyróżnionych częściach Listu, choć trzeba stwierdzić, że jej intensywność wykazuje pewne wahania. Ciągłość i transpozycja ukazana jest już na początku prologu, w części pierwszej wiąże się z problemem wyższości Jezusa nad Aniołami, w części drugiej ukazuje się w związku z typologią Mojżesz - Chrystus. Najbardziej wyraźnie ukazane są oba prawa w centralnej części trzeciej, gdzie wyraźnie zostało stwierdzone, że rzeczywistość starego przymierza jest cieniem rzeczywistości przyszłych, które zostały zaprowadzone przez dzieło Chrystusa. W następnej części zagadnienie ciągłości i transpozycji wiąże się z ukazaniem dziejów Starego Testamentu przez pryzmat wiary, którą Jezus wydoskonala. W ostatniej części Listu znajduje się ważne przeciwstawienie, którego właściwe odczytanie podkreśla ciągłość ekonomii zbawczej i transpozycję nowego przymierza. Przebogaty obraz Syjonu nowego przymierza, wkomponowany w całość Listu do Hebrajczyków, pokazuje raz jeszcze, jakim jest dotykalny cień rzeczy niebieskich i jakimi są one same. Raz jeszcze jest to wielkie wezwanie do wierności.

Przeprowadziwszy ten przegląd możemy wyciągnąć odpowiednie wnioski, do których on nas upoważnia. List do Hebrajczyków bardzo szeroko opisuje rzeczywistość starego i nowego przymierza. Stanowią one jedną całość, w któ-

${ }^{10}$ Rzeczywistość eschatologiczna w Liście do Hebrajczyków, tamże 1 (1969) s. 157. 
rej przede wszystkim realizuje się ciągłość ekonomii zbawczej. Jezus, przynosząc nową rzeczywistość, nie przekreśla poprzedniego etapu, ale go kontynuuje. Kontynuacja ta jest jednak tak bogata i doskonała, że etap poprzedni staje się zaledwie cieniem. Szczepan stanął wobec oskarżenia, że Jezus niszczy wartości starego przymierza. Jego argumentacja musiała dążyć do ukazania ciągłości, aby obalić zarzut zwalczania, oraz ukazania transpozycji, aby zaapelować o przyjęcie tego, co jest dalszym ciągiem, ale o wiele doskonalszym, a przez swą doskonałość pewnym zaprzeczeniem tego, co jeszcze nie jest doskonałe. Szczepanowi nie dane było przeprowadzić tej całej argumentacji. Jego wywód ogranicza się do pozytywnego przedstawienia dziejów Izraela, czym przygotowuje ukazanie ciągłości. Po wzmiance o Sprawiedliwym, który kontynuuje historię Izraela podzielając los proroków, Szczepan zostaje ukamienowany. List do Hebrajczyków podejmując niedokończone słowo Szczepana podkreśla ciągłość i transpozycję, doprowadza argumentację do końca, ukazuje bogactwo nowej rzeczywistości, które domaga się pójścia za nim. W sytuacji, w jakiej pisany jest List, nie grozi już pokusa pozostania czy powrotu do poprzedniego etapu. Świadczy to także o późnym czasie napisania Listu. Pamiętamy, ile wysiłku musiał włożyć św. Paweł w zwalczanie wpływów judeochrześcijan, którzy nie rozumieli, że prawa ciągłości i transpozycji, rządzące objawieniem się Boga, wymagają porzucenia tego, co niepełne i zapowiadające coś innego, na rzecz tego pełnego i zapowiadanego. Autor Listu do Hebrajczyków tych problemów już nie ma. Ukazuje ciągłość i transpozycję. Jego adresaci przyjęli nowe przymierze, nie przystąpili do tego, co dotykalne, lecz przystąpili do Góry Syjon jako synonimu nowej rzeczywistości. Pojawiła się jednak inna pokusa, pokusa niewierności. Zwyczajem niektórych stało się opuszczanie wspólnych zebrań $(10,25)$. Do wszystkich zagrożonych tą pokusą Autor Listu do Hebrajczyków kieruje usilne wezwanie o wierność. Wezwanie to jest logicznym wnioskiem z przedstawionej transpozycji. Im doskonalsza jest rzeczywistość, do której przystępujemy, tym więcej jest zobowiązująca. Teoretyczne prawdy, a zwłaszcza ukazanie ciągłości i transpozycji, nie są w Liście do Hebrajczyków same dla siebie. Autor Listu do Hebrajczyków jest wiernym uczniem św. Pawła, w którego imieniu ten List pisze. Logos służy etosowi, a etos znajduje w logosie silną podstawę. Pod tym względem słusznie przypisano List do Hebrajczyków św. Pawłowi i zaliczono go do zestawu jego pism (Corpus Paulinum). W nim Paweł nie tylko wypłaca się ze swej odpowiedzialności za niedokończone słowo Szczepana ${ }^{11}$, ale także wzywa do wierności opierając tę parenezę na solidnym wykładzie prawd wiary.

${ }^{11}$ Por. T. Jelonek, Problem autorstwa..., s. 212 n. 


\title{
REGULAE REVELATIONIS BIBLICAE: CONTINUITAS ET TRANSPOSITIO IN EPISTOLA AD HEBRAEOS
}

\begin{abstract}
Argumentum
Scriptura sacra est revelans sermo Dei Spiritu Sancto afflante inscripta. Indolem revelationis biblicae sanctus Augustinus notis verbis descripsit: In Vetere Novum latet et in Novo Vetus patet. In hac revelatione progressus existit, cuius regulae continuitas et transpositio sunt.

Hoc in articulo regulae istae in Epistola ad Hebraeos investigatae sunt. Epistola ad Hebraeos liber singularis et magni momenti est. In problemate eius auctoris et genesis novam hipothesim in alio articulo praesentavimus (cf. supra adnotationem 3). Epistola ad Hebraeos est continuatio interruptae sermonis Stephani, quae in septimo capite Actuum Apostolorum invenitur, et responsio ad protestationes Iudeorum contra Stephanum, qui propter destructionem loci sancti et eiectionem Mosaicae legis accusatus est. Responsio, quae in Epistola ad Hebraeos invenitur, praesertium continuationem oeconomiae salutis ostendit. Jesus, quem Stephanus proclamavit, neque locum sanctum neque legem Sinaitici foederis destruxit, sed ita perfecta adimplevit ut vetus realitas nonnisi umbra novae sit. Tota Epistola ad Hebraeos hanc sententiam continet et in multis locis eius exempla ostendit.

Haec thesis de continuitate et transpositione revelationis dicit et est thesis generalis Epistolae ad Hebraeos. Regulae continuitatis et transpositionis ergo in Epistola magni sunt momenti. Praesentatio earum in singulis partibus Epistolae ad Hebraeos in arciculo facta est. In prima parte Jesus angelos antecedit, in secunda parte continuitas et transpositio in typologia Moyses - Christus illustrata est. Pars tertia veterem testamentum ut umbram rerum caelestium ostendit. In Quarta parte Epistolae Christus fidem perficit. In parte ultima praesertim in oppositione ex 12,18-24 continuitas et transpositio Epistolae ad Hebraeos specialis elucet. In omnibus locis doctrina de continuitate et transpositione vocationi ad fidelitatem servit. Maior perfectio maiorem fidelitatem postulat.
\end{abstract}

